\title{
Correction to: Symbiotic Parameters, Productivity and Profitability in Kabuli Chickpea (Cicer arietinum L.) as Influenced by Application of Phosphorus and Biofertilizers
}

\author{
Diljeet Kaur ${ }^{1} \cdot$ Guriqbal Singh $^{2}$ (D) Poonam Sharma ${ }^{2}$ \\ Published online: 28 August 2020 \\ (C) Sociedad Chilena de la Ciencia del Suelo 2020
}

\section{Correction to: Journal of Soil Science and Plant Nutrition https://doi.org/10.1007/s42729-020-00293-z}

There were the following errors in this article as originally published:

On the fourth page of the article, in equation on B:C ratio, $\$$ symbol was missing in the denominator.

On the tenth page of the artice, under 3.8 Economic Analysis, in the 6th line, the citation "(Table 9)." between" fertilizer." and "The highest".

On the thirteenth page of the article, in the paragraph that begins with "The increase in grain yield" "Table 4" should have read "Table 5" and "Table 5" should have read "Table 4".
On the thirteenth page of the artice, under 4.2 Effect of Phosphorus, in the last sentence of the first paragraph, a space belonged between 60 and DAS and between 90 and DAS.

On the fourteenth page of the article, an erroneous Table 10 was presented that repeated the data given in Table 9 in the article.

The original article has been corrected.

Publisher's note Springer Nature remains neutral with regard to jurisdictional claims in published maps and institutional affiliations.
The online version of the original article can be found at https://doi.org/ 10.1007/s42729-020-00293-Z

Guriqbal Singh

singhguriqbal@pau.edu

1 Department of Agronomy, Punjab Agricultural University, Ludhiana, Punjab 141004, India

2 Department of Plant Breeding and Genetics, Punjab Agricultural University, Ludhiana, Punjab 141004, India 